\title{
Bantuan Langsung Tunai
}

\author{
Selviana \\ Irwan Akib \\ Universitas Muhammadiyah Makassar \\ irwanakib@unismuh.ac.id
}

\begin{abstract}
ABSTRAK
Kemiskinan telah hadir dalam realitas kehidupan manusia dengan bentuk dan kondisi yang sangat memprihatinkan, Karena kemiskinan memang tidak bisa dihilangkan begitu saja. Dengan adanya permasalahan terhadap Negara berkembang terutama kemiskinan.Maka pemerintah membuat kebijakan-kebijakan atau program-program untuk memberantas masalah tersebut. Jenis Penelitian yang digunakan adalah deskriptif kualitatif dengan dengan cara penentuan sampel melalui teknik Purposive Sampling dengan memilih beberapa informan yang memiliki kriteria yang telah ditentukan oleh peneliti yakni yang mengetahui tentang dampak bantuan langsung tunai. Penelitian ini bertujuan untuk mengetahui implementasi bantuan langsung tunai dan dampak bantuan langsung tunai terhadap kehidupan sosial ekonomi masyarakat.Hasil penelitian menunjukkan bahwa dalam implementasi bantuan langsung tunai banyak mengalami kendala di pendataan seperti ada beberapa masyarakat yang tidak terdata dalam sasaran rumah tangga miskin serta tidak adanya sosialisasi pemerintah tentang bantuan langsung tunai hal inilah yang menyebabkan ada beberapa masyarakat yg berkategori miskin tidak menerima bantuan.Dan dampak bantuan langsung tunai terhadap kehidupan sosial ekonomi masyarakat yaitu berdampak positif terhadap pemenuhan kebutuhan hidup masyarakat miskin meskipun dalam jangka pendek dan dampak negatifnya yaitu tidak efektif dan efisien bahkan hanya menyebabkan masyarakat ketergantungan terhadap bantuan pemerintah.
\end{abstract}

Kata Kunci : Bantuan Langsung Tunai, Masyarakat, Miskin.

\section{PENDAHULUAN}

Kemiskinan adalah masalah sosial yang masih belum terselesaikan di negara berkembang khususnya di indonesia. Kemiskinan telah hadir dalam realitas kehidupan manusia dengan bentuk dan kondisi yang sangat memprihatinkan, Karena kemiskinan memang tidak bisa dihilangkan begitu saja. Dengan adanya permasalahan terhadap Negara berkembang terutama kemiskinan.Maka pemerintah membuat kebijakankebijakan atau program-program untuk memberantas masalah tersebut.Diantaranya adalah Bantuan langsung tunai atau biasa disebut BLT. Bantuan Langsung Tunai (BLT) dapat dipahami sebagai pemberian sejumlah uang (dana tunai) kepada masyarakat miskin setelah pemerintah memutuskan untuk menaikkan harga BBM dengan jalan mengurangi subsidi namun selisih dari subsidi itu diberikan kepada masyarakat miskin. BLT 
merupakan implementasi dari Instruksi Presiden Nomor 3 Tahun 2008 tentang pelaksanaan program bantuan langsung tunai (BLT) untuk rumah tangga sasaran (RTS) dalam rangka kompensasi pengurangan subsidi BBM. Program BLT-RTS ini dalam pelaksanaanya harus langsung menyentuh dan memberikan manfaat langsung kepada masyarakat miskin (yang terkategori sebagai RTS), mendorong tanggung jawab sosial bersama dan dapat menumbuhkan kepercayaan masyarakat kepada pemerintah yang secara konsisten mesti benar-benar memperhatikan Rumah Tangga Sasaran yang pasti merasakan beban berat sebagai akibat dari kenaikan harga BBM. Program BLT dirancang sebagai pengganti kenaikan biaya hidup ketika terjadi kenaikan harga BBM oleh karena itu, besaran BLT dihitung sebagai kenaikan biaya hidup penduduk miskin disebabkan kenaikan harga (inflasi) yang diakibatkan langsung maupun tidak langsung oleh kenaikan harga BBM.Melihat dari program pemerintah tersebut, upaya pemberantasan kemiskinan di negara Indonesia ini cukup menarik simpati masyarakat. Sehingga masyarakat awam beramai-ramai memuji pemerintah atas program BLT. Tidak mengherankan jika kemudian masyarakat pada taraf kategori mampu pun ikut menjadikan diri sebagai sasaran BLT. Tetapi program pemerintah ini dirasa kurang efektif.Karena Bantuan ini sedikitnya mempunyai dua efek positif, pertama untuk menambah daya beli rakyat miskin yang pendapatannya makin turun dibawah kebutuhan rata-rata normal. Kedua, menyuntikkan dana ke wilayah miskin untuk menghidupkan daya beli yang relatif sudah sangat rendah. Dalam hal pemberian BLT ke masyarakat miskin ini tentunya ada persyaratan atau kriteria khusus.Tetapi kenyataan fungsi BLT ada yang menyalahgunakan.Fungsinya hanya membantu untuk mencukupi kebutuhan sehari-hari tetapi orang menggunakannya untuk hal yang dirasa kurang penting. Seperti tukang becak biasanya uang BLT tersebut digunakan untuk membeli Rokok .dan ada juga yang digunakan untuk membeli baju atau sepatu. Intinya digunakan untuk kebutuhankebutuhan yang dirasa kurang penting untuk kebutuhan mereka. Selain fungsi yang disalahgunakan, Validitas data masyarakat miskin yang diragukan sehingga akan berdampak pada ketepatan pemberian dana BLT kepada masyarakat yang berhak. Seringkali data untuk persyaratan tersebut dipalsukan, Maka bukan orang miskin lagi yang menerima Bisa saja orang lain.

\section{PENDAHULUAN}

Menurut para ahli seperti Andre Bayo Ala (1981:120),kemiskinan sangat multidimensional, artinya kemiskinan mempunyai banyak aspek sebab kebutuhan setiap 
manusia sangat beragam.Kemiskinan ditinjau dari sisi kebijakan umum terdiri dari dua aspek, yaitu primer dan sekunder. Aspek primer merupakan miskin akan aset, organisasi sosial politik, serta pengetahuan dan keterampilan. Menurut Suparlan bahwa kemiskinan adalah suatu standar hidup yang rendah yaitu: adanya suatu tingkat kekurangan materi pada sejumlah atau segolongan orang yang dibandingkan dengan standar kehidupannyang umum berlaku dalam masyarakat bersangkutan. Standar hidup yang rendah ini secara langsung nampak mempengaruhi terhadap tingkat kesehatan, kehidupan moral, dan rasa harga diri dari mereka yang tergolong miskin" (Juwanita, 2004:13).Kemiskinan dapat diartikan sebagai kekurangan sumber daya yang dapat digunakan untuk meningkatkan kesejahteraan masyarakat.Jika diartikan dengan pendapatan dan kebutuhan dasar maka kemiskinan dapat diukur secara langsung, yaitu ketika pendapatan masyarakat tidak dapat memenuhi kebutuhan dasar minimum maka orang ini dapat dikatakan miskin.Dalam hal ini kemiskinan ditentukan oleh keadaan tidak tercapainya kebutuhan dasar sesuai dengan kebutuhan saat ini. Ukuran atau kategori kemiskinan menurut BPS (2005) antara lain:

a. Penduduk miskin dikatakan sangat miskin apabila kemampuan untuk memenuhi konsumsi makanan hanya mencapai 1900 kalori per orang per hari ditambah kebutuhan dasar non makanan, atau setara dengan Rp 120.000,- per orang/perbulan.

b. Penduduk dikatakan miskin apabila kemampuan memenuhi konsumsi makanan hanya mencapai antara 1900-2100 kalori/orang ditambah kebutuhan dasar non makanan, atau setara Rp.150.000,- per orang per bulan.

c. Penduduk dikatakan mendekati miskin apabila kemampuan memenuhi konsumsi hanya mencapai antara 2100-2300 kalori ditambah kebutuhan dasar non-makanan atau setara Rp 175.000,- per orang per hari.

Program Bantuan Langsung Tunai telah dilaksanakan Pemerintah Indonesia. Tujuan dari Program Bantuan Langsung Tunai bagi Rumah Tangga Sasaran dalam rangka kompensasi pengurangan subsidi BBM adalah:Membantu masyarakat miskin agar tetap dapat memenuhi kebutuhan dasarnya.

1. Mencegah penurunan taraf kesejahteraan masyarakat miskin akibat kesulitan ekonomi. 2. Meningkatkan tanggung jawab sosial bersama (Depsos, 2008).

Penerima BLT adalah Rumah Tangga Sasaran (RTS) sebanyak 19, 1 juta RTS hasil pendataan BPS, yang meliputi rumah tangga sangat miskin (poorest), rumah tangga miskin (poor), dan rumah tangga hampir miskin (near poor) di seluruh wilayah Indonesia. 
Besarnya bantuan yang diterima masyarakat sebesar $\mathrm{Rp} 100.000$ tiap bulan per Rumah Tangga Sasaran (RTS). Syarat masyarakat / warga miskin yang berhak menerima program Bantuan Langsung Tunai (BLT) minimal harus memenuhi 9 (Sembilan) syarat dari 14 (empat belas) syarat sesuai dengan ketetapan pemerintah, sebagaimana di jelaskan pada Tabel 1.1 berikut:

Tabel 2.1

Syarat warga miskin yang dapat menerima Bantuan LangsungTunai (BLT)

\begin{tabular}{|l|l|l|}
\hline No & \multicolumn{1}{|c|}{ Variabel } & \multicolumn{1}{c|}{ Kriteria } \\
\hline 1 & $\begin{array}{l}\text { Luas lantai bangunan tempat } \\
\text { tinggal. }\end{array}$ & Kurang dari 8 (delapan) $\mathrm{m}^{2} /$ orang. \\
\hline 2 & $\begin{array}{l}\text { Jenis lantai bangunan tempat } \\
\text { tinggal. }\end{array}$ & $\begin{array}{l}\text { Tanah/Bambu/Kayu murahan/Semen } \\
\text { kualitas jelek. }\end{array}$ \\
\hline 3 & Jenis dinding tempat tinggal. & $\begin{array}{l}\text { Bambu/Rumbia/Kayu kualitas rendah / } \\
\text { tembok tanpa plester. }\end{array}$ \\
\hline 4 & Fasilitas tempat buang air besar & Tidak punya / bersama. \\
\hline 5 & Sumber penerangan utama. & Bukan listrik \\
\hline 6 & Bahan bakar untuk masak. & Kayu bakar / Arang / Minyak tanah. \\
\hline 7 & $\begin{array}{l}\text { Konsumsi daging / susu / ayam } \\
\text { per minggu }\end{array}$ & $\begin{array}{l}\text { Tidak pernah mengkonsumsi / hanya satu } \\
\text { kali dalam seminggu. }\end{array}$ \\
\hline 8 & Sumber air minum & $\begin{array}{l}\text { Sumur/Mata air tidak terlindungi/Sungai/ } \\
\text { Air hujan. }\end{array}$ \\
\hline 9 & $\begin{array}{l}\text { Pembelian pakaian baru untuk } \\
\text { setiap anggota rumah tangga } \\
\text { dalam setahun. }\end{array}$ & $\begin{array}{l}\text { Tidak pernah membeli/Hanya membeli satu } \\
\text { stel dalam setahun }\end{array}$ \\
\hline 10 & $\begin{array}{l}\text { Makan malam sehari untuk setiap } \\
\text { anggota rumah tangga. }\end{array}$ & Hanya satu/dua kali makan dalam sehari. \\
\hline
\end{tabular}

Menurut Bernard Raho (2007: 48) Fungsionalisme struktural adalah salah satu paham atau perspektif di dalam sosiologi yang memandang masyarakat sebagai satu sistem yang terdiri dari bagian-bagian yang saling berhubungan satu sama lain dan bagian yang satu tak dapat berfungsi tanpa ada hubungan dengan bagian yang lain. Kemudian, perubahan yang terjadi pada salah satu bagian akan menyebabkan ketidakseimbangan dan pada gilirannya akan menciptakan perubahan pada bagian lain.Masyarakat terdiri dari 
berbagai elemen atau institusi.Elemen-elemen itu antara lain adalah ekonomi, politik, hukum, agama, pendidikan, keluarga, kebudayaan, adat-istiadat dan lain-lain. Seturut pandangan teori ini, masyarakat luas akan berjalan normal kalau masing-masing elemen atau institusi menjalankan fungsinya dengan baik. Kemacetan pada salah satu institusi akan menyebabkan kemacetan pada institusi-institusi lain dan pada gilirannya akan menciptakan kemacetan pada masyarakat secara keseluruhan.

\section{METODE PENELITIAN}

Jenis penelitian yang dilakukan adalah penelitian deskriptif kualitatif yang bertujuan untuk memahami fenomena atau realitas sosial tentang Dampak Bantuan Langsung Tunai (studi kasus pada masyarakat di kelurahan karema kecamatan mamuju kabupaten mamuju).Informan ditentukan secara purposive sampling, dan juga menggunakan sumber data primer dan data sekunder, teknik pengumpulan data yaitu observasi, wawancara dan dokumentasi, kemudian dianalisis melalui tahapan pengumpulan data (data collection), reduksi data (data reduction), penyajian data (display data), penarikan kesimpulan (verification).

\section{PEMBAHASAN}

Salah satu program pemerintah untuk mengurangi kemiskinan atau memajukan kesejahteraan umum adalah dengan memberikan Bantuan Langsung Tunai (BLT). Bantuan langsung tunai (BLT) mulai terlaksana melalui Instruksi Presiden Nomor 12 tahun 2005 , tentang "pelaksanaan Bantuan Langsung Tunai kepada rumah tangga miskin" dan Instruksi Presiden Republik Indonesia No.3 Tahun 2008, tentang “ pelaksanaan Bantuan Langsung Tunai untuk rumah tangga sasaran”. Tujuan yang diharapkan melalui kebijakan program ini adalah dapat menjawab persoalan kemiskinan di Indonesia, sebagai akibat dari segenap perubahan yang telah terjadi, baik secara nasional maupun global.Sebagai suatu program dan kebijakan nasional, program BLT mempunyai latar belakang pelaksanaan yang sistimatis, baik secara deskriptif analisis kondisional maupun deskriptif operasional perundang-undangan. Setelah Pemerintah memutuskan untuk menaikan BBM, kebijakan Bantuan Langsung Tunai (BLT) menjadi kebijakan turunan dari kebijakan kenaikan BBM tersebut.Kebijakan BLT yang diluncurkan pemerintah ini, menuai banyak protes mulai dari masyarakat, pemerintah daerah, mahasiswa, dan tokoh-tokoh masyarakat baik nasional maupun daerah. Kebijakan 
yang sama juga pernah dilakukan oleh pemerintah pada tahun 2005, ketika pemerintah menaikan BBM sebesar 126 persen (Sirait 2008).

Keadaan ini mendorong pemerintah untuk melakukan pendekatan subsidi secara langsung yang tertuang dalam BLT.Akan tetapi, kebijakan Bantuan Langsung Tunai (BLT) kepada rumah tangga miskin sebagai kompensasi pengurangan subsidi BBM telah menimbulkan kontroversi dan masalah baru. Jika ditinjau dari sisi waktu keluarnya payung hukum hingga pelaksanaan yang hanya dalam waktu singkat, sangat terasa kebijakan BLT terburu-buru dan dipaksakan, tidak mengherankan jika kemudian timbul banyak masalah antara lain belum adanya kesamaan pemahaman antara berbagai instansi pemerintah, media, maupun masyarakat. Hal ini terlihat dari penggunaan istilah yang berbeda-beda.Ada yang menyebutnya Program Kompensasi Pengurangan Subsidi (PKPS), Dana Kompensasi BBM (DKM), atau Bantuan Tunai Langsung (BTL) (Dharmawan 2008).Ini bukti lemahnya sosialisasi pemerintah tentang program ini.Dalam pelaksanaan kebijakan tidak selalu berjalan lancar, pasti akan ada yang menjadi faktor penghambatnya, begitu pula dengan implementasi Bantuan Langsung Tunai (BLT) di Kelurahan Karema Kecamatan Mamuju Kabupaten Mamuju, sebagian penduduk atau masyarakat miskin tidak menerima Bantuan tersebut dengan alasan tidak terdaftar sebagai penerima bantuan sedangkan fakta di lapangan yang saya temukan masyarakat yang mampu atau dengan kata lain Kepala keluarganya memiliki penghasilan tetap setiap bulannya menerima bantuan tersebut.

Permasalahan mengenai pendataan memang menjadi titik lemah utama.Kebanyakan warga tidak mengetahui kapan dilakukan pendataan. Warga juga tidak mengetahui secara pasti kriteria rumah tangga miskin yang berhak menerima BLT.Selain itu, sebagian warga bekerja di luar daerah domisili sebagaimana tertera dalam dokumen kependudukan, sehingga tidak terdaftar atau terdata secara ganda di tempat domisili dan di tempat daerah bekerja.Akibat lemahya pendataan, sebagai warga yang benar-benar miskin justru tidak terdata.Sehingga untuk mengatasi hal ini penggunaan metode BLT menuntut data yang akurat dan terpecaya, padahal untuk Indonesia perkembangan sistem informasi masih dianggap kurang.Ketidaktepatan dalam mendata RTS (Rumah Tangga Sasaran), di sebabkan petugas pendata, tidak mematuhi kriteria yang ditetapkan (memenuhi minimal 9 kriteria dari 14 kriteria syarat penerima BLT). Data yang tidak valid, menyebabkan kesalahan dalam pembagian dana BLT yang seharusnya diberikan kepada orang yang berhak menerimanya, akibatnya sebagian dari warga miskin mengeluhkan kejadian tersebut, karena mereka yang seharusnya masuk dalam daftar RTS 
(Rumah Tangga Sasaran) tidak mendapat dana bantuan. Pendataan warga perlu dilakukan setiap periodenya, agar sewaktu BLT akan dilaksanakan, petugas pendata mendapatkan data valid mengenai jumlah warga miskin yang berhak menerima BLT, karena perubahan ekonomi yang terjadi setiap saat dapat menyebabkan taraf hidup warga yang berubahubah pula.

Menurut hasil penelitian di lapangan ada 22 kepala keluarga tidak mampu yang tidak menerima BLT, sebagian dari keluarga ini menolak untuk diwanwancarai. Hasil ini saya ketahui melalui wawancara dengan masyarakat kelurahan Karema yang bersedia untuk di wawancarai dan dianggap mengetahui tentang pendataan penerima BLT tersebutSelain itu Dampak BLT terhadap kesejahteraan rakyat terlihat pada prioritas masyarakat miskin dimana prioritas penggunaan uang BLT paling utama adalah sembako. Hal ini menunjukan bahwa BLT belum efisien dalam memenuhi kebutuhan masyarakat miskin karena prioritas utama dari BLT tersebut masih untuk kebutuhan dasar.Namun BLT tersebut memiliki manfaat yang sangat besar bagi kelangsungan hidup masyarakat miskin terutama dalam pemenuhan kebutuhan.Selain itu BLT tidak terpengaruh terhadap kinerja masyarakat miskin karena masyarakat miskin tidak bisa hidup jika hanya menggantungkan penerimaannya pada BLT.Di satu sisi, kebijakan BLT ini mungkin akan memberikan dampak positif bagi masyarakat miskin. Dengan BLT, kenaikan biaya hidup yang diakibatkan oleh kenaikan BBM secara langsung maupun dampak kenaikan harga kebutuhan pokok akibat kenaikan BBM, akan sedikit tertutupi dengan adanya dana “ Cuma-Cuma" yang diberikan oleh pemerintah. Akan tetapi disisi lain kebijakan BLT ini memiliki dampak yang negatif juga yaitu kebijakan ini akan berdampak negatif pada perilaku dan karakter masyarakat.Adanya kebijakan ini membuat masyarakat menjadi manja Selain itu juga, permasalahan efektfitas dan efesiensi kebijakan ini sangat diragukan.Banyak kelemahan-kelemahan dan masalah-masalah yang ditimbulkan oleh kebijakan BLT ini, antara lain :

1. Kebijakan BLT bukan kebijakan yang efektif dan efisien untuk menyelesaikan kemiskinan di Indonesia, ini dikarenakan kebijakan ini tidak mampu meningkatkan derajat dan tingkat kesejahteraan masyarakat miskin.

2. Efektifitas dan efisiensi penggunaan dana BLT yang tidak dapat diukur dan diawasi karena lemahnya fungsi pengawasan pemerintah terhadap kebijakan tersebut.

3. Kebijakan BLT memiliki kecenderungan menjadi pemicu konflik sosial di masyarakat. 
4. Validitas data masyarakat miskin yang diragukan sehingga akan berdampak pada ketepatan pemberian dana BLT kepada masyarakat yang berhak

5. Peran aktif masyarakat yang kurang / minim, sehingga optimalisasi kinerja program yang sulit direalisasikan

6. Dari sisi keuangan negara, kebijakan BLT merupakan kebijakan yang bersifat menghambur-hamburkan uang negara karena kebijakan tersebut tidak mampu menyelesaikan masalah kemiskinan secara berkelanjutan dan tidak mampu menstimulus produktifitas masyarakat miskin.

Agar program BLT dapat menjadi bantuan yang efektif dan efisien, maka diperlukan beberapa langkah, yaitu:

1. Manajemen penyaluran dana yang baik dan sistematis, agar tercapai tujuan dari program BLT yang sebenarnya yaitu untuk mensejahterakan masyarakat kecil.

2. Diperlukan pengawasan terhadap penyaluran dana BLT, karena banyak ditemukan kesalahan-kesalahan yang menyebabkan program BLT tidak dapat berjalan sesuai dengan rencana.

3. Bantuan dana langsug tidak diberikan dalam bentuk uang tunai yang diberikan cumacuma kepada masyarakat karena dikhawatirkan masyarakat hanya akan bergantung pada BLT, maka bantuan dana langsung direalisasikan dalam bentuk bantuan dana untuk usaha sehingga dari dana tersebut membuka lapangan pekerjaan baru bagi masyarakat agar tidak menjadi masyarakat yang pemalas karena hanya menggantungkan dari bantuan selain itu dapat mengurangi tinkat pengangguran.

Pemberian bantuan terhadap masyarakat miskin merupakan hal yang harus dilakukan pemerintah untuk penentasan masalah kemiskinan agar kesejahteraan masyarakat meningkat namun kenyataan yang terjadi di masyarakat bantuan langsung tunai bukan menjadi jawaban permasalahan kemiskinan di Indonesia.Karena dampak yang ditimbulkan bukan hanya sisi positifnya saja melainkan banyak juga membawa dampak yang negatif sehingga peningkatan kesejahteraan masyarakat melalui bantuan langsung tunai itu dianggap belum maksimal dalam membantu perekonomian masyarakat.Pengentasan masalah kemiskinan bukan hanya tugas pemerintah saja melainkan masyarakat juga punya peran penting dalam hal ini.Masyarakat itu sendiri juga harusnya mampu mengolah atau memanfaatkan bantuan yang diberikan oleh pemerintah agar dapat meningkatkan kesejahteraannya untuk hidup yang lebih baik. 


\section{KESIMPULAN}

Setelah melakukan penelitian, maka peneliti dapat menyimpulkan beberapa kesimpulan untuk menjawab masalah yang di angkat dalam penelitian ini, kesimpulan yang dapat ditarik yaitu :

1. Implementasi bantuan langsung tunai dikelurahan karema kecamatan mamuju kabupaten mamuju hampir semua sudah mengenai rumah tangga sasaran tetapi ada beberapa masyarakat yang tidak tersentuh bantuan hal ini disebabkan karena pendataan yang dilakukan tidak menyentuh semua sasaran rumah tangga miskin dan kurangnya sosialisasi dari pemerintah tentang program bantuan langsung tunai sehingga banyak masyarakat miskin yang belum tersentuh atau menerima bantuan padahal masyarakat tersebut layak untuk menerima bantuan

2. dampak bantuan langsung tunai terhadap kehidupan sosial ekonomi masyarakat adalah bantuan langsung tunai ini dianggap tidak efektif dan efisien karena kurang membantu dalam peningkatan perekonomian masyarakat hal ini disebabkan masyarakat menggunakan dana tersebut bukan untuk jangka panjang atau bukan untuk modal usaha melainkan untuk kebutuhan sehari-hari dan dampak lainnya y masyarakat menjadi ketergantungan terhadap bantuan langsung tunai karena masyarakat terus mengharapkan bantuan dari pemerintah.

\section{Daftar Pustaka}

Adisasmita, Rahardjo., (2015). Analisis kebijakan publik. Yogyakarta: Graha ilmu.

Amalmey.,()2009.,(Online)(http://amalmey.files.wordpress.com. di akses tanggal 22 November 2015)

AnNaf,Julissar.,(2007).(Online)(http://julissarwritting.blogspot.com/2007/11/pengentasan kemiskinan.html. diakses tanggal 3 Mei 2015)

Arikunto., (1993). Metodologi Penelitian Deskriptif. Yogyakarta.

Asnaeni, St., (2013).Perubahan Perilaku Sosial -Budaya Studi Pada Masyarakat Penerima Bantuan Langsung Tunai Di Kelurahan Batangkaluku Kabupaten Gowa. Gowa: Penelitian Dosen Pemula.

Badan Pusat Statistik. (2000). Tingkat Kemiskinan Kabupaten (Penjelasan Ringkas). Jakarta.

Badan Pusat Statistik. (2005). Petunjuk Pendistribusian Kartu Kompensasi BBM 2005, Jakarta. 
Bagong, Suyanto., (1996). Perangkat Kemiskinan Problema dan Strategi Pengentasannya Dalam Pembangunan.Jakarta : Aditya Media.

Departemen Sosial RI.(2008). Petunjuk Teknis Program Bantuan Langsung Tunai kepada Rumah Tangga Sasaran. Jakarta: Depsos RI.

Ikbar, Yanuar., (2012). Metode Penelitian Sosial Kualtatif. Bandung: Refika aditama.

Narwoko, Dwi, J., (2011). Sosiologi Teks Pengantar Dan Terapan. Jakarta: Kencana.

Purnomo, Dony., (2012). Sisi Negatif Bantuan Langsung Tunai.(Online). (http://pinterdw.blogspot.com, diakses tanggal 5 Mei 2015)

Raho, Bernard., (2007). Teori Sosiologi Modern. Jakarta: Prestasi pustaka.

Said, Juwanita.(2004). Tesis.Perempuan dan Kemiskinan.Makassar : Pascasarjana Unhas.

Septhani, putri, Bernica., (2013).Keefektifan Program Pemerintah Dalam Mengatasi Ketimpangan Pendapatan Masyarakat Miskin Melalui Bantuan Langsung Tunai (blt). (Online) (https://putribernica.files.wordpress.com, diakses tanggal 5 Mei2015 )

Soekanto, Soerjono., (2012). Sosiologi Suatu Pengantar. Jakarta: PT. Rajawali Pers.

Sugiyono., (2011). Metode Penelitian Deskriptif Kualitatif. Bandung: Alfabeta.

Sumardi, M. \& Hans-Dieter Evers. (1994). Kemiskinan dan Kebutuhan Pokok. Kota terbit : Rajawali Pers.

Sumrah At. (2008). Tesis.Kemiskinan dan Strategi Kelangsungan Hidup.Bulukumba : Pascasarjana.

Wahyu., (2010). MetodePenelitian Untuk Penelitian Deskriptif Kualitatif. Banjarmasin. 